\title{
Serum uric acid concentrations in a Xhosa community in the Transkei of Southern Africa
}

\author{
PETER BEIGHTON, GUY DAYNES, AND COLIN L. SOSKOLNE \\ From the Department of Human Genetics, Medical School, University of Cape Town; St. Lucy's Hospital, \\ St. Cuthbert's Mission, Tsolo, Transkei; and the National Research Institute for Occupational Diseases of \\ the South African Medical Research Council, Johannesburg, S.A.
}

\begin{abstract}
Beighton, P., Daynes, G., and Soskolne, C. L. (1976). Annals of the Rheumatic Diseases, 35, 77-80. Serum uric acid concentrations in a Xhosa community in the Transkei of Southern Africa. Serum uric acid (SUA) concentrations were measured in specimens obtained from 479 respondents aged 15 and over during an epidemiological survey of bone and joint conditions in a tribal Xhosa community living in the Transkei, Southern Africa.

Population SUA levels in the Xhosa were significantly lower than those previously observed in South African Negro groups in rural and urban environments. This finding agrees with the observation that population SUA concentrations tend to rise with increasing complexity of life style.
\end{abstract}

Serum uric acid (SUA) levels are affected by both genetic and environmental influences ( $O$ 'Brien, Burch and Bunim, 1966). The importance of the latter factors has been clearly established in comparative studies of rural (semisophisticated) and urban communities of African Negro peoples, in which it has been shown that the urbanized group have significantly higher SUA concentrations (Beighton and others, 1973, 1974).

In order to complete the series of surveys of African Negro communities living in different circumstances, we have studied an unsophisticated tribal Xhosa population in the Transkei and report here the results of SUA investigations in this group.

\section{Population and environment}

The population studied were members of the Mpondomisi tribe, a subdivision of the Xhosa people. The Xhosa of the Transkei are descendants of African Negroes who have migrated from Central Africa during the past 2000 years. They are closely related to other Negro groups in Southern Africa, such as the Tswana and Zulu, and they have a degree of Xhoisan (Bushman and Hottentot) admixture.

The community inhabited the villages of Zincuka and Esingeni, to which they had moved in 1880 , following the 'Gun War'. The incumbents of St. Cuthbert's mission began their evangelicization and education during this period, and in the last decade of the 19th century the hosAccepted for publication July 9, 1975.

Correspondence to Professor P. Beighton, Dept. of Human Genetics, Medical School, University of Cape Town, Observatory 7900, South Africa. pital of St. Lucy's was established to provide medical care. Trading stores which were opened in the district at this time accentuated the influence of 'Westernized' way of life.

The villages of Zincuka and Esingeni are situated in the Tsolo district of the Transkei in the foothills of the Drakensberg mountains on the eastern side of Southern Africa, latitude $31^{\circ} \mathrm{S}$, longitude $29^{\circ} \mathrm{E}$, altitude 1200 metres. The summer months are warm, with afternoon thunderstorms, while the winters are dry with cold nights.

Many members of the communities still follow an unsophisticated life style, adhering to tribal customs. The main activities are the cultivation of maize and cattle husbandry. As with other African groups, the males often migrate to find work in the industrial conurbations, and their remittances are the economic mainstay of the community.

\section{Methods}

The method of investigation was similar to that used in previous studies of African Negro populations by the Department of Orthopaedic Surgery, University of the Witwatersrand (Beighton and others, 1973, 1974).

A census was first taken (under the direction of G.D.) in two adjacent villages served by St. Lucy's Hospital, St. Cuthbert's Mission, Tsolo, Transkei. In one village the census included the whole population of approximately 500 individuals. In the other a well-defined area was chosen by random use of a map and grid, containing sufficient huts to provide a further 500 potential respon- 
dents. The population was then investigated clinically and radiologically by a team from the Department of Human Genetics, University of Cape Town, using the facilities of St. Lucy's Hospital. Blood specimens were obtained from individuals aged 15 and over and separated within 4 hours of collection. Frozen sera were transported by air to Cape Town in insulated containers and SUA concentrations were determined by the automated modification of the Folin method.

Data were analysed by computer and the ponderal index of each adult was calculated by dividing the height in inches by the cube root of the weight in pounds.

For individuals aged 15 and over completion rates were $94 \%$ for clinical exmaination, $91 \%$ for radiological examination, and $86 \%$ for SUA estimation.

\section{Results}

The inhabitants of the Xhosa villages were of identical stock, differing only slightly in the degree of sophistication of their life style. For this reason their SUA findings were evaluated separately, but no differences emerged and the results of analysis of pooled data are given below.

SUA estimations were carried out on 80 males and 399 females. (The relative paucity of males in the population is the consequence of labour migration and is a common feature of most nonurban Negro communities in Southern Africa.)

Gout was not encountered in any of the respondents.

Table I SUA concentrations in Xhosa males

\begin{tabular}{|c|c|c|c|c|}
\hline \multirow{2}{*}{$\begin{array}{l}\text { Age } \\
\text { (years) }\end{array}$} & \multirow[t]{2}{*}{ No. } & \multirow{2}{*}{$\begin{array}{l}\text { Mean SUA } \\
\mathrm{mmol} / \mathrm{l}(\mathrm{mg} / 100 \mathrm{ml})\end{array}$} & \multicolumn{2}{|l|}{ Range } \\
\hline & & & Low & High \\
\hline $\begin{array}{l}15-24 \\
25-44 \\
45-64 \\
65+\end{array}$ & $\begin{array}{l}11 \\
14 \\
31 \\
24\end{array}$ & $\begin{array}{l}0.245(4 \cdot 2) \\
0.268(4 \cdot 5) \\
0 \cdot 286(4 \cdot 8) \\
0 \cdot 298(5 \cdot 0)\end{array}$ & $\begin{array}{l}0.190(3 \cdot 2) \\
0.196(3 \cdot 3) \\
0.161(2 \cdot 7) \\
0.179(3 \cdot 0)\end{array}$ & $\begin{array}{l}0.381(6 \cdot 4) \\
0.387(6 \cdot 5) \\
0.375(6 \cdot 3) \\
0.428(7 \cdot 2)\end{array}$ \\
\hline Total & 80 & $0.280(4 \cdot 7)$ & $0 \cdot 161(2 \cdot 7)$ & $0.428(7 \cdot 2)$ \\
\hline Table II & ncent & hosa females & & \\
\hline \multirow{2}{*}{$\begin{array}{l}\text { Age } \\
\text { (years) }\end{array}$} & \multirow[t]{2}{*}{ No. } & \multirow{2}{*}{$\begin{array}{l}\text { Mean SUA } \\
\mathrm{mmol} / \mathrm{l}(\mathrm{mg} / 100 \mathrm{ml})\end{array}$} & \multicolumn{2}{|l|}{ Range } \\
\hline & & & Low & High \\
\hline $\begin{array}{l}15-19 \\
20-24 \\
25-34 \\
35-44 \\
45-54 \\
55-64 \\
65-74 \\
75+\end{array}$ & $\begin{array}{r}26 \\
30 \\
106 \\
85 \\
53 \\
48 \\
38 \\
13\end{array}$ & $\begin{array}{l}0.220(3 \cdot 7) \\
0.214(3 \cdot 6) \\
0.220(3 \cdot 7) \\
0.226(3 \cdot 8) \\
0.238(4 \cdot 0) \\
0.256(4 \cdot 3) \\
0.244(4 \cdot 1) \\
0.238(4 \cdot 0)\end{array}$ & $\begin{array}{l}0.143(2.4) \\
0.119(2.0) \\
0.095(1.6) \\
0.119(2.0) \\
0.119(2.0) \\
0.125(2.1) \\
0.125(2.1) \\
0.143(2.4)\end{array}$ & $\begin{array}{l}0.340(5.7) \\
0.369(6.2) \\
0.363(6.1) \\
0.440(7.4) \\
0.363(6.1) \\
0.399(6.7) \\
0.340(5.7) \\
0.298(5.0)\end{array}$ \\
\hline Total & 399 & $0.232(3.9)$ & $0.095(1.6)$ & $0.440(7 \cdot 4)$ \\
\hline
\end{tabular}

Table III Comparative data on SUA concentrations in South African Negro populations

\begin{tabular}{|c|c|c|c|c|c|}
\hline & \multirow{2}{*}{$\begin{array}{l}\text { Age } \\
\text { (years) }\end{array}$} & \multirow[t]{2}{*}{ No. } & \multirow{2}{*}{$\begin{array}{l}S U A \\
\mathrm{mmol} / \mathrm{l}(\mathrm{mg} / 100 \mathrm{ml})\end{array}$} & \multicolumn{2}{|l|}{ Range } \\
\hline & & & & Low & High \\
\hline $\begin{array}{l}\text { Males } \\
\text { Xhosa (tribal) } \\
\text { Tswana (rural) } \\
\text { Soweto (urban) }\end{array}$ & $\begin{array}{l}18-75+ \\
14-84 \\
15-90\end{array}$ & $\begin{array}{r}80 \\
128 \\
144\end{array}$ & $\begin{array}{l}0.274(4 \cdot 6) \\
0.292(4 \cdot 9) \\
0.363(6 \cdot 1)\end{array}$ & $\begin{array}{l}0.161(2.7) \\
0.173(2.9) \\
0.060(1.0)\end{array}$ & $\begin{array}{l}0.428(7.2) \\
0.631(10.6) \\
0.589(9.9)\end{array}$ \\
\hline $\begin{array}{l}\text { Females } \\
\text { Xhosa (tribal) } \\
\text { Tswana (rural) } \\
\text { Soweto (urban) }\end{array}$ & $\begin{array}{l}15-75+ \\
14-96 \\
15-90\end{array}$ & $\begin{array}{l}399 \\
242 \\
280\end{array}$ & $\begin{array}{l}0.232(3 \cdot 9) \\
0 \cdot 268(4 \cdot 5) \\
0.309(5 \cdot 2)\end{array}$ & $\begin{array}{l}0.095(1 \cdot 6) \\
0.065(1 \cdot 1) \\
0.155(2.6)\end{array}$ & $\begin{array}{l}0.440(7 \cdot 4) \\
0.660(11 \cdot 1) \\
0.571(9 \cdot 6)\end{array}$ \\
\hline
\end{tabular}




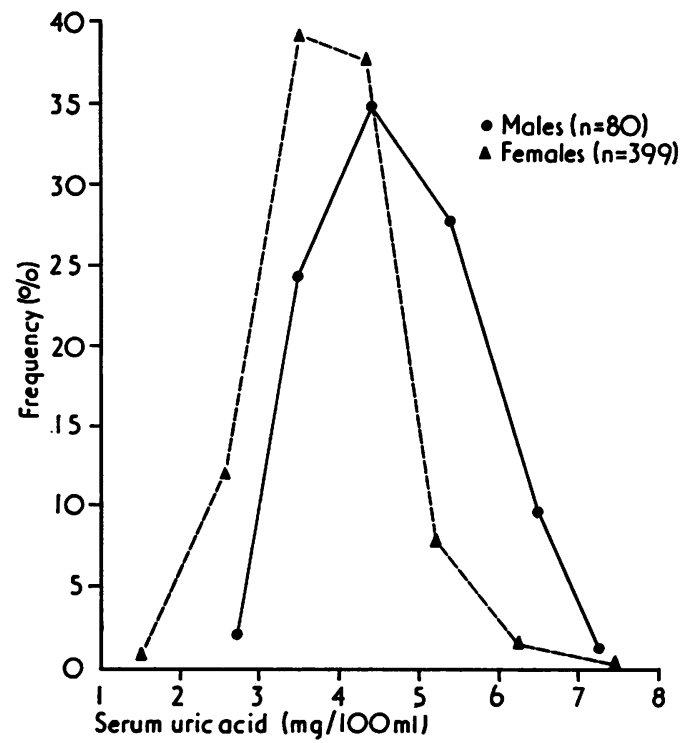

FIGURE Frequency distribution of $S U A$ concentrations in Xhosa males and females. Conversion factor: Traditional units to SI-SUA: $1 \mathrm{mg} / 100 \mathrm{ml} \approx 0.0595 \mathrm{mmol} / 1$

The mean and range of SUA values by age group for males and females are given in Tables I and II, the values for males being consistently higher than those for females in each group. A few SUA levels fell outside the usual range of $0.208-0.417 \mathrm{mmol} / 1$ $(3.5-7.0 \mathrm{mg} / 100 \mathrm{ml})$ for males, and $0.208-0.357$ $\mathrm{mmol} / 1 \mathrm{(3.5}-6.0 \mathrm{mg} / 100 \mathrm{ml})$ for females, but were normal in the majority. The mean SUA levels in the African Negro populations previously studied are shown in Table III for comparison.

The age-sex relationship of SUA levels were also evaluated separately for each of the two Xhosa communities. The fitted curves indicated no significant differences in SUA levels at any given age, and this was confirmed by Student's ' $t$ ' test $(P<0 \cdot 5)$.

The frequency distribution curves for SUA levels for males and females are shown in the Figure.The unimodality of the curves is consistent with a normal distribution of SUA levels within the community.

The relationship between SUA and ponderal index for respondents aged 20 and over is shown in Table
IV. The correlation coefficients indicate a positive relationship between SUA levels and increasing obesity for the males, whereas no such association is shown in females.

\section{Discussion}

The investigation of SUA concentrations in the Xhosa of the Transkei completes the series of studies of African Negroes living at different socioeconomic levels, in tribal, rural, and urban environments.

The tendency of population SUA levels to rise with increasing sophistication and complexity of life style is clearly shown in Table III, indicating that SUA concentrations may play a part in the aetiology of conditions such as myocardial infarction and hypertension, which are becoming more common in urbanized South African Negroes, although these disorders are still uncommon in rural areas. Gout, the clinical expression of hyperuricaemia, follows a similar pattern.

The three Negro populations investigated in this series are all closely related genetically and it is therefore likely that the differences in population SUA levels that have been shown are the result of environmental influences, the exact nature of which is unknown. Diet may be an important determinant. However, the rural and urban communities previously studied had different overall SUA concentrations in spite of a similar 'Westernized' diet, and the inhabitants of the two Xhosa villages in the present study had certain dietary differences but the age-sex relationships of their population SUA levels were identical. Other factors must also play a part.

The Xhosa community lived at a comparable altitude to the rural and urbanized populations previously studied and other environmental influences, such as endemic infections, were similar in each of the communities. Furthermore, as the mean ponderal indices of the adult males and females in these populations were similar, differences in SUA level cannot be attributed to body size. (Mean ponderal indices in adult males-tribal 12.91, rural 12.99, urban 12.63; adult females-tribal 12.44, rural 12.06, urban $11 \cdot 56$.)

The results of the Xhosa survey agree with the previously reported trend for SUA levels to rise with

Table IV SUA concentrations and ponderal index in the Xhosa

\begin{tabular}{|c|c|c|c|c|c|}
\hline Sex & $\begin{array}{l}\text { Ponderal } \\
\text { index } \\
\text { (no. of cases) }\end{array}$ & $S D$ & $\begin{array}{l}\text { Correlation } \\
\text { coefficient } \\
\text { (no. of cases) }\end{array}$ & $\begin{array}{l}\text { SUA } \\
\text { (no. of cases) }\end{array}$ & $S D$ \\
\hline Male & $12 \cdot 91$ & 0.929 & $\begin{array}{l}-0.327 \\
(61)\end{array}$ & $\begin{array}{l}4 \cdot 7 \\
(74)\end{array}$ & 1.05 \\
\hline Female & $\begin{array}{l}12 \cdot 44 \\
(400)\end{array}$ & 0.930 & $\begin{array}{l}+0.006 \\
(347)\end{array}$ & $\begin{array}{l}3.59 \\
(373)\end{array}$ & 0.85 \\
\hline
\end{tabular}


the increasing sophistication of way of life (Popert and Hewitt, 1962; Rose and Prior, 1963). A further step will be to study the relationship between SUA concentrations and common disease processes, which also have a changing prevalence. Similarly, potential environmental determinants of SUA concentrations will be selected for scrutiny to establish the extent of their influence upon this course of events.

The earlier surveys of rural and urban African communities were made under the aegis of Professor Louis
Solomon, Department of Orthopaedic Surgery, University of the Witwatersrand, Johannesburg.

We are grateful to the Xhosa community for their willing participation, and to the Department of Bantu Administration for their permission for the survey to be carried out. We are indebted to the Department of Biochemistry, Groote Schuur Hospital, for measuring the SUA levels, and to Mrs. Greta Beighton for preparing the illustration and typing the manuscript. The investigation was supported by grants from the South African Medical Research Council and the University of Cape Town staff research fund.

\section{References}

Beighton, P., Solomon, L., Soskolne, C. L., And Sweet, B. (1973) Ann. rheum. Dis., 32, 3 (Serum uric acid concentrations in a rural Tswana community in Southern Africa)

,,,,---- AND RobIN, G. (1974) Ibid., 33, 442 (Serum uric acid concentrations in an urbanized South African Negro population)

O’Brien, W. M., Burch, T. A., AND Bunim, J. J. (1966) Ibid., 25, 117 (Genetics of hyperuricaemia in Blackfeet and Pima Indians)

Popert, A. J., AND HewitT, J. V. (1962) Ibid., 21, 154 (Gout and hyperuricaemia in rural and urban populations)

Rose, B. S., AND PRIOR, I. A. M. (1963) Ibid., 22, 410 (A survey of rheumatism in a rural New Zealand Maori community)

Correction: 'Synthetic D(-)penicillamine in rheumatoid arthritis. Double-blind controlled study of a high and low regimen.' By Dixon et al. Annals, October 1975, 34, 416.

Page 416, column 2, line 10 should read, 'The material contains less than $0.3 \%$ of the optical isomer, $\mathrm{L}(+)$ penicillamine, which is regarded as toxic.' 